'His Brothers' Keeper:

John Brown, Moral Stewardship, and Interracial Abolitionism’

W. Caleb McDaniel

Rice University

This is an electronic, post-print version of an article published in the journal Slavery and Abolition 32, no. 1 (March 2011), 27-52. To cite the article, please consult the final published version available online at:

\title{
http://dx.doi.org/10.1080/0144039X.2011.538197
}

Recent biographies of abolitionist John Brown emphasize his uniqueness and cast him as an anomalous figure in the antislavery movement. This article, however, makes the case for Brown's representativeness by connecting his career to his formative years in northeastern Ohio, a geographical and cultural context that shaped Brown's lifelong image of himself as an advisor and manager of wilderness communities. That self-image made Brown similar to white 'moral stewards' in many reform movements. Even Brown's interracial relationships, though difficult to interpret because of sparse documentary evidence, were shaped partly by the culture of moral stewardship in which Brown's career began. 
The militant abolitionist John Brown is now increasingly remembered as a visionary egalitarian who 'seeded' the modern Civil Rights movement and, 'virtually alone among nineteenth century white Americans,' forged 'personal relationships with black people that were sustained, intimate, trusting, and egalitarian.' Indeed, the emerging consensus is that Brown was an egalitarian without equals - an utterly unique figure whose views were closer to those of contemporary scholars than they were to Brown's own peers. According to one recent biographer, the unique intimacy of Brown's interracial relationships even suggests that he adopted a black identity or 'black heart' and, unlike most abolitionists, understood race and gender as 'social constructs.'

Such claims imply that Brown marked the boundaries of 'what was possible' for abolitionists before the Civil War, for if, as John Stauffer writes, Brown was 'in no way "representative" of broader currents in antebellum America, how we see Brown affects how we see abolitionists generally. Some recent biographers claim that other white abolitionists pale next to Brown, compared to whom even abolitionists like William Lloyd Garrison appear condescending and compromised by racial prejudice. Garrison's 'racial openness' was not as thoroughgoing as Brown's, writes David Reynolds in one such passage, since Garrison 'thought [blacks] must be educated before being granted full social rights' and since some of his interracial relationships - most notably with Frederick Douglass — were strained. Assertions about Brown's singularity are thus remapping the geography of antebellum abolitionism as an island and a continent, with an exceeding few like Brown who transcended race, separated by a wide gulf from the many who did not. The current stakes in understanding Brown are therefore nothing less than the nature of abolitionism as a whole and the limits of interracialism in antebellum America. ${ }^{2}$ 
The tendency of biographers to emphasize Brown's uniqueness dates to the immediate aftermath of his famous Harpers Ferry raid, when admirers like Ralph Waldo Emerson and Henry David Thoreau praised Brown as a peerless, messianic figure. Subsequent writers likewise treated Brown less as an archetype of nineteenth-century reform than as an anomaly—a 'meteor,' to use Walt Whitman's metaphor, rather than part of a larger constellation of American reform. His earliest abolitionist biographers reached for characters from earlier times, like Cromwell or Christ, to find the nearest analogies for Brown. Many proslavery critics alleged that Brown typified abolitionism, but that tendentious accusation only encouraged admiring Northern writers to distance themselves from Brown by praising his distinctive virtues. Later, champions of Brown like W. E. B. Du Bois, no less than critics like James Malin, based their praise or their criticism of Brown on his uniqueness. In a formulation that has since become very influential, Du Bois even argued that Brown was 'the man who of all Americans has perhaps come nearest to touching the real souls of black folk. ${ }^{3}$ As historian Mary Land noticed sixty years ago, the result of this long-standing emphasis on Brown's uniqueness has been a tendency to see his activities as 'unrelated to the organized antislavery movement' and instead as 'projections of his own personal loathing of slavery.' Even the frequent attention by biographers to Brown's stern Calvinism has perpetuated the idea that he was not a man of his time and place, but a 'belated Covenanter'-more akin to Puritans than to contemporaries like Garrison or Theodore Dwight Weld. $^{4}$

For two reasons, however, this article challenges the prevailing image of Brown as a singular anomaly. First, claims about the uniqueness of Brown's interracial relationships rest on an often ambiguous and fragmentary documentary record. While Du Bois's depiction of Brown as someone who achieved rare 'intimacy' with black abolitionists remains influential, Du Bois 
also offered a cautionary reminder that 'few written records of this long continued intimacy now exist.' The documents we do have about Brown's interracial relationships were very often created by Brown, his family, or his white admirers, which limits our ability to discern much from them about the way that people of color viewed their relationships with Brown at the time. In some cases, historians have even relied on Brown's own writings, like the essays 'Sambo's Mistakes' and 'Words of Advice,' to draw conclusions about how others viewed Brown, despite the lack of decisive evidence about how African Americans interpreted these essays. To be sure, African American testimonials to Brown's virtues proliferated after his execution, but it is often difficult to separate the myth that Brown became in death from reliable evidence of the man that he was in life. It remains more difficult to know what many of Brown's presumably most intimate interracial relationships were actually like than some recent biographers have allowed. ${ }^{5}$

Recent scholarship has also understated many ways in which Brown's career exemplified common patterns in antebellum reform. Brown's life—including his interracial relationshipswere shaped by social and cultural sources that shaped many other antebellum abolitionists whom he resembled. In fact, I argue here that he was in large part a recognizable product of the reform culture of the Western Reserve of Ohio, an area where Brown lived for the majority of his life. Although the case for Brown's representativeness has seldom been made, my account depicts Brown as a 'moral steward' who joined various other reformers' attempts to civilize the Ohio frontier and who adopted an identity similar to theirs. ${ }^{6}$

To underline Brown's connections with and similarities to broader reform contexts, I use the term 'moral steward' in conscious allusion to the bundle of ideals and identities that historian Clifford S. Griffin once called 'moral stewardship.' For Griffin, 'moral stewards' referred to the Protestant founders of the so-called Benevolent Empire of antebellum reform societies, who 
sought to create and maintain social order primarily through programs of individual conversion and uplift that they, as 'moral stewards,' believed themselves uniquely qualified to direct. These groups included, for Griffin, the American Bible, American Tract, American Education, and American Home Missionary Societies, as well as many early antislavery organizations. What Griffin saw among the leaders of such groups was a shared sense that most of their contemporaries needed improving if American society was to remain civil and godly. These 'moral stewards' also believed they were uniquely qualified to direct that improvement. They were 'their brothers' keepers,' social trustees whose right and duty was 'to tell other men how to

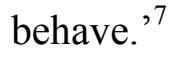

Griffin overstated the coherence of moral stewards as a group and sometimes oversimplified their trusteeship as a form of social control. But 'moral stewardship' remains a useful token for the worldview of those Connecticut Congregationalists and Presbyterians who, at the turn of the nineteenth century, began populating northeastern Ohio, the region where Brown lived for most of his life. When placed in that geographical and historical context, Brown's life quickly reveals many commonalities with 'moral stewards' to whom he is seldom compared. Moreover, Brown's indebtedness to the culture of 'moral stewardship' helps explain a great deal about his life, including key aspects of his earliest and latest antislavery plans, his lifelong interest in settling areas perceived as wildernesses in order to create model frontier communities, and — not least—his often-noted imperiousness. More than just a temperamental tic, Brown's habit of advising others and insisting on deference to his leadership was a cultural legacy from the many decades he spent in the West.

Seeing Brown as a 'moral steward' is important because it helps us better understand the man, but it may be even more important as an aid to understanding the nature of antebellum 
reform and interracial abolitionism. The dominant tendency to see Brown as an anomalous harbinger of things to come risks evaluating the ideals and practices of nineteenth-century abolitionists by anachronistic standards. But locating Brown in his historical context as a 'moral steward' enables us to evaluate interracial abolitionism on its own terms. The major gain of this approach, to which I will return in the conclusion, is that it underscores how the very same cultural forces that made white abolitionists pursue interracial relationships simultaneously encouraged imperious habits of advising that risked straining those relationships-in Brown's case as well as in Garrison's.

\section{'Hudson and Thereabouts'}

Any attempt to understand John Brown must begin where he began: in the West. In 1805, at age five, Brown moved from his birthplace, Connecticut, to Hudson, Ohio, joining a growing stream of New Englanders to the 'Western Reserve.' Many came with the Connecticut Land Company, which began surveying and selling lots in the 1790s. Others came with the Connecticut Missionary Society, which organized 'home missions' to frontier communities. But whether as surveyors or missionaries, New Englanders arrived envisioning Ohio, in Brown's later words, as a 'wilderness filled with wild beasts, \& Indians.' Their errand was to civilize a wilderness — or, as one missionary put it, to turn Ohio into a 'moral garden of the Western world'-a mission that would engage Brown's commitment and shape his identity for the rest of his life. ${ }^{8}$

The civilizing mission of New Englanders in Ohio involved both spatial and moral order. Surveyors sought to reshape the land by converting forests into farms and gridded towns. Home missionaries sought to reform settlers by inculcating industry, thrift, and piety. Yet spatial and moral order were deeply related for New Connecticut's trustees. Disordered space—weedy fields 
and open pasture — signified spiritual laxity, while visible order — plat lines and fruited plains signaled the progress of missionaries in reforming the population. The same men often served as both surveyors and missionaries. Missionary Society officer Abel Flint wrote a surveying manual. David Hudson, founder of the eponymous town, came to the 'howling wilderness' to serve God. When not preaching, missionaries like David Bacon planned bridges and cleared trees. Intent on turning Ohio into a 'moral garden,' such men assumed the responsibility for both the spatial and moral ordering of the frontier. Brown spent his formative years in a culture in which a good 'moral steward' was also a moral gardener, a role that was equal parts surveyor and missionary. ${ }^{9}$

If certain kinds of individuals were required in moral gardens, so were certain institutions. The Western Reserve possessed a disproportionate number of Ohio's schools between 1800 and 1850 , and the 1820 s and 1830 s witnessed the proliferation of colleges like the Oberlin Institute and Lane Seminary in Cincinnati. Many of these colleges were influenced by the 'manual labor' movement, an educational reform influential in the West partly because it comported so well with the visions of 'moral gardeners.' The Society for Promoting Manual Labor in Literary Institutions, whose agent was future abolitionist Theodore Dwight Weld, criticized existing seminaries for focusing exclusively on young ministers' minds. Sedentary study, according to Weld and others, was creating an entire generation of ministers with puny physiques, disdain for work, and few 'useful' skills. Their solution was the establishment of colleges that combined study with mandatory exercise and labor on farms and in workshops. Weld himself studied at such a school, the Oneida Institute in New York, but in 1832, the manual labor Society dispatched him to make Lane Seminary their flagship. ${ }^{10}$

Manual labor curricula appealed in Ohio partly because they promised to train ministers 
who could plant and survey, as well as preach sermons. Supporters also envisioned manual labor colleges as moral gardens in microcosm. John Jay Shipherd, who came to Ohio as a missionary and later founded Oberlin on the 'manual labor' system, understood his college as a model colony as much as a school. He required students to exercise and worked to encourage 'muscular, mental + moral vigor,' but Shipherd also intended Oberlin to exemplify spatial order. By clearing woods and erecting a campus, his students would simultaneously learn 'elevated personal piety' and visibly mark the arrival of order in the wilderness. Fittingly, Oberlinites represented their 'Plan of Oberlin Colony' in 1835 with a surveyor's map. ${ }^{11}$

The year after that map was drawn, John Brown's father, Owen, became an Oberlin trustee, and shortly thereafter Oberlin hired John Brown as a surveyor. But long before, father and son shared the visions of spatial and social order that brought missionary-surveyors to Ohio. Owen decided to move to Ohio after a visit from Bacon, the home missionary, and once there, Owen became an active steward of spatial order-building a tannery, locating his house on the town green, and frequently traveling 'into the woods to make devisians of lands.' In the local Congregational church Owen also served as a steward of spiritual order and joined David Hudson in a local branch of the American Education Society, which at the time endorsed 'manual labor.' Not surprisingly, Owen's dual interest in spatial and spiritual order also combined and culminated in a school. In 1825, when Hudson elites gathered to found Western Reserve College, which adopted some manual labor ideas, Owen was on the committee for campus construction. ${ }^{12}$

In an 1821 autobiographical narrative, Owen recalled that he came to Hudson not to live in a 'land of idleness' but to 'help in the seport of religion and civil Order.' His support for that civilizing mission was confirmed by the company he kept, which was, he recalled, 'of the best 
kind[,] the Missionaries of the Gospel and leading men' of 'business' throughout the Western Reserve. Owen's association with missionary-surveyors suggests he shared their vision of order and their understanding of who the 'best' people were. Looking back on his own life, Owen rued that he had not always associated with the 'better class of people.' But after experiencing a wave of revivals in adolescence, Brown met Christian men who gave him 'a great deal of instruction' and 'good council.' Their 'influence' inspired him to 'improve' himself in 'industry and frugality,' and by 1821, Owen saw himself as the head of an 'orderly' family in his own right and his own brothers' keeper, whose job was now to influence others as early advisors influenced him. ${ }^{13}$

John Brown deeply imbibed Owen's example as a steward of spatial and spiritual order. Around 1820, he learned surveying from the manual of missionary-surveyor Abel Flint, and in 1826, Brown took his family to support order in another 'wilderness' - Crawford County, Pennsylvania. There, Brown cleared land, built a tannery, introduced agricultural improvements, and organized a church. He served as Postmaster, quizzed and lectured newcomers about schools and Sabbath observance, and joined a chapter of the American Bible Society. Brown served as trustee for an association that maintained a local road and started a small school for his and a neighbor's children. As one of Brown's employees, James Foreman, later remembered, Brown busied himself with 'Surveying out new Roads' and 'building School Houses[,]' and 'encouraging every thing which would have a moral tendency to improve the country,' like circulating 'good moral books and papers,' much like the New England moral stewards behind the Tract Society. In short, Brown supported both spatial order and moral order. One of his students, George Delamater, recalled that Brown was 'intent' not just on 'business' and 'the improvement of the country,' but on 'the education and improvement of his family and friends, 
[and] with other projects of public interest or utility.' He had learned well the role of a 'New Connecticut' man. ${ }^{14}$

Owen's roles at Western Reserve and later at Oberlin make it probable he and John also sympathized with 'manual labor.' John's abortive career as a seminary student in the East may have encouraged skepticism about conventional curricula, for in the 1840s John enrolled his oldest son in the Grand River Institute in Austinburg, originally founded on manual labor principles and affiliated with Oberlin. Sympathy for manual laborism would also explain why, according to Delamater, Brown promoted both 'physical and mental culture' in his Pennsylvania school and organized 'contests of strength and skill,' which Brown believed were 'not mere amusement, but also a means of strengthening the muscles. ${ }^{15}$

Such memories suggest that Brown saw Crawford County much like Shipherd saw Oberlin, a colony-qua-school where he could cultivate moral, mental, and muscular vigor. More than just a disposition, his urge to advise, improve, and order was a cultural patrimony, and after returning to Hudson in 1835, Brown tried to pass the same inheritance to his son. In an 1841 letter to John Jr., then a schoolteacher struggling to manage his students, Brown asked, 'If you cannot now go into a disordered country school and ... reduce it to good order ... then how how how are you to stimulate Asses to attempt a passage of the Alps'? The rhetorical question revealed the high stakes involved in Brown's own felt duty to reduce 'disordered' country to 'order.' Brown's advice to his son—one of many instances in which Brown urged his children to heed his counsel — helped him meet his primary obligation as a man: to instruct his own family. But both John and his father saw themselves as their brothers' keepers as well, and their neighbors also needed instruction on everything from shearing sheep to Sabbath observance. As Brown told John Jr. in his 1841 letter, he believed that in every decision, no matter how 
insignificant, 'one course is right, \& another wrong.' And when Brown eventually left 'Hudson and thereabouts,' he carried a deeply felt duty to tell others which was which. ${ }^{16}$

Brown also left Ohio an abolitionist. Though many antislavery Ohioans supported the expatriation of free blacks to Africa, John and Owen belonged to Ohio's small number of activists who, in the 1830s, demanded immediate emancipation without colonization. Yet Brown's identity as an immediatist did not supplant his identity as a moral steward. While Western abolitionists dissented sharply from their contemporaries on slavery and race, they generally shared the mission to make Ohio a 'moral garden.' Indeed, in Ohio, organized abolitionism centered around colleges, the frontline institutions in the errand to civilize the wilderness. In 1834, at Lane, a group of abolitionist students and teachers who had forged ties with free black neighborhoods denounced colonizationism. These 'Lane Rebels' moved to Oberlin, thereafter the anti-colonizationist bulwark. But Ohio's earliest revolt against colonization occurred in Hudson itself and involved Owen Brown. In 1832, three professors at Western Reserve College-Beriah Green, Charles Storrs, and Elizur Wright—were forced to leave for supporting 'immediate emancipation.' Owen defended the renegades, joined Wright to found the Western Reserve Anti-Slavery Society in 1833, and threw his support to Oberlin, serving as a trustee from 1836 to $1844 .{ }^{17}$

John Brown was across the state line when the Hudson and Lane uprisings took place, but events in Ohio may help explain a letter Brown wrote to his brother Frederick in 1834. Brown reported that he and his family were planning 'to get at least one negro boy,' bring him into their home, and raise the youth 'as we do our own,--viz., give him a good English education, learn him what we can about the history of the world, about business, about general subjects, and, above all, try to teach him the fear of God.' Additionally, Brown told Frederick that he had 'for 
years been trying to devise some way to get a school a-going here for blacks.' This was his 'favorite theme of reflection,' for 'whether they are all to be immediately set free or not,' black children deserved and needed education. Brown urged Frederick to get 'from Hudson and thereabouts some first-rate abolitionist families' to support his school. ${ }^{18}$

The collegiate origins of Ohio abolitionism explain both why Brown expected to find supporters in 'Hudson and thereabouts' and also why his earliest antislavery plan involved founding a school. Oberlin admitted black students in 1835, and even before then, Lane Rebels organized a lyceum among Cincinnati's black neighborhoods, where white students lectured several times a week with the aim, in Weld's words, of 'elevating the colored people.' Brown's plan to educate 'blacks' thus closely resembled contemporaneous plans by area abolitionists. Elevating colored people was also a unifying agenda for anti-colonizationists in New England, where black and white abolitionists in the early 1830s also advocated black 'manual labor' schools. As historian Lawrence J. Friedman notes, white anti-colonizationists in the 1830s characteristically described themselves as 'elevators,' 'instructors,' and 'adviser[s]' to black Northerners. But this was especially true in the Western Reserve, where many abolitionists were already educators, missionaries, and community leaders inclined to see themselves as 'instructors' and 'adviser[s].' While conversion from colonizationism involved an imaginative expansion of the racial boundaries of moral gardens, abolitionists were still moral gardeners on a civilizing errand. They assimilated new tasks as antislavery reformers into that larger cultural enterprise. $^{19}$

That continuity, even amidst conversion, helps explain why so many proposals for 'elevating the colored people' called specifically for 'manual labor' schools. The bankrollers of the anti-colonizationist movement—-like Gerrit Smith and Lewis Tappan—also funded manual 
laborism, whose leading figures, like Weld, were often abolitionists. The Lane rebellion occurred at the 'manual labor' flagship and resulted in the Rebels' defection to another manual labor school. And when Beriah Green was forced to leave Hudson, he became president of the manuallabor Oneida Institute in New York. While making new demands for black elevation, these abolitionists drew on deeply rooted ideas about what elevation required—not just academic instruction, but training in physical labor, abstemious lifestyles, and personal piety. ${ }^{20}$

Continuity also marked the early abolitionism of Owen and John Brown. In his 1834 letter, John envisioned the adoption of a black child and the creation of a black school as continuations of existing responsibilities; he hoped to raise the boy 'as we do our own,' and the curriculum Brown proposed to teach—not just bookish subjects, but 'business' skills and 'the fear of God'-suggest the holistic pedagogy behind manual laborism. In an 1837 letter to the Ohio AntiSlavery Society, Owen also urged the formation of an 'Anti-slavery Education Society,' believing it imperative that people of color receive schooling. Denying them education 'shuts out this class of people from most of the privileges of other benevolent societies, as that of the Bible and Tract Societies, and even the Home Mission Society is of but little use.' Ignorance, in other words, placed people of color beyond the reach of their brothers' keepers: 'much kind advice and instruction are lost, such as are necessary to regulate their conduct, make them good members of religious and civil society, make them useful and happy neighbors, lessen their crimes, and raise their prospects for time and eternity. ${ }^{21}$

Both Owen and John Brown initially saw abolitionism as compatible with their duties to offer 'kind advice and instruction' to others, to support religious and civil order, to be 'useful' and to make their neighbors 'useful.' Although the personal financial disasters wrought by the Panic of 1837, not abolitionism, consumed Brown's attention for the next decade, there is little 
evidence of diminution in ideas and identities he had formed during his first forty years. On the contrary, one often overlooked episode suggests that even in 1840, Brown still viewed himself less as a full-time abolitionist than as a moral gardener who could settle and supervise new country.

In 1840, Oberlin, thanks to Owen's role as trustee, hired John to survey some Virginia lands donated to the college by Gerrit Smith. Oberlin officials saw the job, predictably, as the first step in making the Virginia 'wilderness [to] bud and blossom as the rose.' Should John 'succeed in clearing up titles,' an Oberlin official told Owen, 'it would be easy ... to make provision for religious and school privileges' in the area. Brown probably shared similar hopes for his mission. Like the missionary-surveyors who preceded him to Ohio and now sent him East, Brown did not simply survey the land. In a letter home, he also surveyed the spatial and spiritual disorder he saw: idle habits had been passed from 'Father to Son,' farms were in disarray, the locals seemed 'to have no Idea of improvement in their Cattle[,] Sheep, or Hogs[,] nor to know the use of enclosed pasture fields for their stock.' What the Virginians needed was someone who could teach them 'how to manage,' and Brown had no doubts about who that someone was: 'I think we might be verry useful to them on many accounts,' he concluded, declaring Virginia 'the spot where ... I hope one day to live with my family., 22

Brown did not go to Virginia-yet. But his interest confirms Foreman's later recollection of Brown as a man who 'Seemed always partial to a new country to improve and help Subdue it and grow up with the improvements made.' Because that partiality stemmed from long decades of living among the West's moral gardeners, it remained central to Brown's self-image and his understanding of the responsibilities of a man. ${ }^{23}$ 


\section{The Responsibilities of a Man}

In 1846, Brown moved to Springfield, Massachusetts, to begin a wool-brokering partnership with Ohio businessman Simon Perkins. Much about Brown changed there. First, he began new relationships with black abolitionists. Brown hired Thomas Thomas, a free black activist and former slave, to work in his wool warehouse. By 1848 he was reading Frederick Douglass's newspaper and the Ram's Horn, a New York City paper edited by black abolitionists Willis Hodges and Thomas van Rensellaer. Brown visited Hodges in New York, and black abolitionists Henry Highland Garnet and Jermain Loguen also learned of Brown, who apparently was hatching new antislavery plans. Douglass first met Brown in Springfield, probably in 1848. He later recalled in 1882 that Brown had then revealed a plan to lead armed men into the Alleghanies and send posses to surrounding plantations to help slaves escape. The 'weak and timid' would be spirited North; the bravest would join Brown's men and help repulse attackers. In this way, using violence only in self-defense, Brown thought he could destroy the 'money value of slave property. ${ }^{24}$

Such plans, together with Brown's acquaintance with Garnet, who endorsed slave insurrection in 1843, may suggest Harper's Ferry was already on the horizon. Yet much about Brown remained unchanged. Brown still viewed his new surroundings with an eye towards improvement—now in wool instead of tanning. Brown also continued to order-in both senses of the word. Douglass recalled Brown's house as austere and well-kept, befitting a steward of spatial order, and added that Brown's orders were unquestioned by his family, who had by then joined him. Before their arrival, Brown worried that distance from home was attenuating his 'influence' over his family and friends, but such worries demonstrate the persistence, not weakening, of Brown's familiar responsibilities. ${ }^{25}$ 
Notwithstanding Douglass's account of the Allegheny plan, Brown's abolitionism also ran in familiar veins in Springfield. In 1847, Brown wrote John Brown Jr. to see if George Delamater, his Pennsylvania pupil who later studied at Allegheny and Oberlin, would be interested in founding an 'Affrican [sic] high school,' which remained one of Brown's favorite themes of reflection. In fact, continued interest in schools may have prompted his new interracial relationships. The black newspapers Brown read often called for black schools, and his new acquaintances Loguen, Garnet, and Augustus Washington had all studied at Oneida, the manual labor college in New York that Beriah Green integrated after leaving Hudson. Perhaps this background, more than premonitions of a Southern invasion, initially provided the common ground on which they and Brown met. ${ }^{26}$

Whatever the reasons, Brown was interacting more than ever before with men of color. But this does not necessarily indicate total transformation in his identity or ideas. His experiences were not notably different from precedents in the West. At Oberlin, white students worked and lived with black students, as later at Oneida. Wright attended a Western Reserve commencement arm in arm with a black abolitionist. The Lane rebellion occurred partly because Weld and white abolitionists forged close relationships with black neighbors. ${ }^{27}$ The interracial sociability Brown experienced first in Springfield was similar to what Weld and others experienced twelve years before, and in both cases, new interracial ties could coexist with a persistent sense of mission to elevate. Just as the Lane Rebels' interracial relationships did not disrupt their self-images as 'elevators,' 'advisors' and 'instructors,' the fact that Brown immediately revived his school idea in Springfield suggests continuity as well as change.

Continuity also explains an otherwise curious essay Brown wrote in 1848 or 1849. In 'Sambo's Mistakes,' an essay addressed to the Ram 's Horn, Brown posed as a black man and 
admonished other black men about their errors. Those mistakes were many: 'Sambo' smoked, read trashy novels, joined secret societies, and wasted money on 'gay clothing[,] nice Canes, Watches, Safety Chains, Finger-rings, Breast Pins,' and candy, rather than investing in a library or farm. Improvidence, ‘Sambo' confessed, had prevented him from gaining 'influence amongst men' or 'employ[ing] others to their benefit \& improvement.' Having become 'without proffit to myself,' 'Sambo' could not claim the 'satisfaction of having benefited others.' He could correct his mistakes, and 'nobly resist' his oppression, only by 'taking my place as a man \& assuming the responsibilities of a man [as] a citizen, a husband, a father, a brother, a neighbour, a friend. ${ }^{, 28}$

Many writers see 'Sambo's Mistakes' either as remarkably innovative or as evidence of the new influence black abolitionists' rhetoric on Brown. Less often noticed are continuities between this sententious essay and Brown's past. The traits 'Sambo' recommended-probity, 'useful knowledge,' 'influence amongst men' — traced the familiar outlines of the 'moral gardener,' and Brown's focus on black uplift echoed other Western abolitionists. His advice that Sambo invest in a 'library' and 'farm' even recalls the manual labor faith in combining study with work.

Brown's disapproval of Sambo's 'gay clothing' and dandyish habits also echoed the anxieties of Ohio's moral stewards. Surveying his life in 1821, Owen Brown regretted his youthful envy of young dilettantes who wasted money on expensive clothes instead of becoming 'men of business,' and manual laborites recommended plain dress and condemned profligate consumption. $^{29}$

Most of all, the very act of writing 'Sambo's Mistakes' was consistent with Brown's identity as his brothers' keeper and underscored that this advisory role was part of the basic 'responsibilities of a man.' In the essay, taking one's 'place as a man' meant becoming able to influence, employ, and improve others, but 'Sambo,' Brown said, had not attained that station 
partly because of his own disregard for 'the company of inteligent wise \& good men from whom I might have learned much that would be interesting, instructive, \& useful.' Brown clearly still identified himself as one of those men who could instruct others. Almost ten years earlier, he had resolved to show Virginians 'how to manage'; now, in Springfield, the audience for his advice had changed, but not his assumption of the responsibility and right to advise. That continuity helps explain why his next move was not to the Alleghanies after all, but to the Adirondacks. ${ }^{30}$

\section{'A Kind of Father to Them'}

Just before Brown arrived in Springfield, abolitionist patron Gerrit Smith announced that he would divide 120,000 acres of his land in upstate New York and donate plots to black men. Although the mostly forested lands were deep in the Adirondack backcountry, black abolitionists praised the plan, particularly in the newspapers Brown began reading in Springfield. Hodges, the Ram's Horn editor, even moved to Franklin County in 1848, while other black New Yorkers settled in North Elba, Essex County. Then, in May 1849, Brown moved his own family to a rented farm near North Elba. ${ }^{31}$

A year before, Brown traveled to New York to meet Smith, afterwards writing John Jr. to see if Delamater could move to North Elba and 'take a general look after the welfare of the collony [sic], \& see to making some beginnings.' But it was not long before Brown was considering looking after the 'infant colony' himself. Brown visited Essex in May, began writing Hodges about the settlements, and sent food for settlers. By January, James H. Henderson, an early settler, told the North Star he had 'seen Mr. J. B., of Springfield, Mass.,' who 'will move here in the Spring, and will give us a start if we will try and help ourselves.' Hodges also expected Brown to 'move out here soon, when he will be a welcome and useful neighbor.' 
Brown discussed the Smith colonies with Douglass, too, perhaps in their earliest interview. Since Douglass's paper in 1847 and 1848 was crowded with lists of emigrants, land advice, and warnings about unscrupulous surveyors, it may even have been Brown's reputation as surveyor that first attracted attention from Smith land promoters. After all, Brown's resume included having surveyed other 'Smith lands' for Oberlin, and black abolitionists may have hoped Brown could vouch for the viability of this new donation. That would explain why Douglass's earliest published mentions of Brown referred to the New York settlements. At one 1848 meeting, Douglass 'alluded prominently to his recent interview with Mr. John Brown, of Springfield, who had but returned from the Lands, and pronounced them good.' In December Douglass printed a letter from Brown advertising himself as an 'experienced Surveyor.' 32

Brown's experience as a surveyor may account not only for the interest of black New Yorkers in Brown, but also for Brown's interest in Essex. Eight years before, he considered moving to Virginia to show residents 'how to manage.' Now, contemplating his move to Essex, he used identical language. In January 1849, Brown told his father he knew 'no place where I think I would sooner go; all things considered than to live with those poor despised Africans to try, \& encourage them; \& show them a little so far as I am capable how to manage.' North Elba beckoned as another wilderness community that needed a moral gardener. When Brown met Smith he reportedly even cited his Western past, introducing himself as 'something of a pioneer' who grew up 'among the woods ... of Ohio' and knew that 'way of life.' He promised he could take a plot, 'clear it up and plant it, and show my colored neighbors how such work should be done ... give them work as I have occasion, look after them in needful ways, and be a kind of father to them. ${ }^{33}$

Although Brown's biographer, Franklin Sanborn, did not reveal that quotation's source, 
Brown's self-description as 'something of a pioneer' and 'a kind of father' rings true and conveyed well his dual self-image as abolitionist and moral gardener. As a chance to bring order to a new wilderness, North Elba would provide Brown with tasks that fulfilled his self-image as a manly advisor and community manager. Meanwhile, as a chance to teach black men specifically how to manage, North Elba realized a vision for being a kind of father to people of color that dated to 1834. As Louis DeCaro suggests, perhaps Brown even saw Essex as the longcherished black school that he mentioned as recently as 1847 , when he considered Delamater, the same man he first approached about looking after the 'collony' in Essex, as a potential leader of an African school. ${ }^{34}$

Of course North Elba was not just a 'school.' But for manual labor abolitionists in Ohio (and in upstate New York, where Oneida was located), schools were colonies: total communities in which students worked, worshipped, and studied together. Perhaps Brown saw Essex as a manual labor school writ large, with himself in the role of an overseer like Shipherd or Green. After all, one of Brown's recommendations in 'Sambo's Mistakes' was that black men flee urban vice and invest in a 'good farm.' Brown probably wrote 'Sambo's Mistakes' while corresponding with Hodges about the Smith lands, and in April 1848, he asked John Jr. to help recruit 'some colored men of the right stamp for colonists.' He may have intended the essay both as a recruitment tool and a sketch of the wrong stamp of men. ${ }^{35}$

Despite its appeal, however, Brown's vision for North Elba never fully materialized. First, Brown was almost never there. Recent descriptions of North Elba as Brown's permanent home obscure the fact that Brown only lived in Essex for two or three months in 1849, perhaps two months in 1850, and about a month in 1855-in all, no more than six, non-consecutive months. In July 1849, having arrived in May, Brown left for a business trip to England. He returned on 9 
November but rushed to Springfield the next week. Future returns were brief. In May 1850, for example, his daughter Ruth told John Jr. that 'Father arrived here yesterday afternoon and is going to start away in the morning.' That year, his longest return came in September to witness Ruth's marriage to Henry Thompson, a local white farmer. But an October trip interrupted even this stay. By Thanksgiving Brown was back in Springfield, remaining until at least late February. Then, in March, all the Browns except Ruth moved back to Ohio. Brown periodically visited the Thompsons, but in his letters he now called Ohio 'home' again. In late June 1855, the Browns moved back to Essex, but the next month, Brown left for Kansas. Subsequent visits to his wife and youngest children, who stayed behind, were few and far between. ${ }^{36}$

After 1849, North Elba's black population also waned. By February 1850, James McCune Smith found only sixty black settlers there and expressed concern that many were becoming dependent on the Browns' 'meal bin.' When the census enumerator arrived in September, he counted about twenty-two people of color. Three years later, Lyman Eppes, the black settler who stayed longest, said 'five colored settlers' remained. The state census of 1855 found forty-one, but the number dropped to twenty-two by 1860 . The period when Brown lived near a sizable black settlement was thus even briefer than the time he spent in Essex, and his relations with black settlers were most often mediated through kin. After 1851, Brown communicated to Eppes through the Thompsons, and even after 1855, most North Elbans probably knew Brown's family better than they knew Brown. ${ }^{37}$

Brown's move to North Elba nonetheless demonstrates that the 'moral gardener' in him was alive and well. Like the missionary-surveyors of Ohio, Brown still presumed himself a 'useful' man who could advise settlers on how to manage. Even before arriving, he sent a steady stream of instructions. 'I would advise ... that you do not go to any expense about voting next 
spring,' he wrote Hodges in January 1849. He advised settlers to 'busy themselves in cutting plenty of hard wood and in getting any work they can find till spring,' and he combined private counsels with authoritative public advice. 'I would recommend to all those that have received lands, or who may hereafter receive lands' never to sell them, Brown told the North Star. ${ }^{38}$ Later, Brown's managerial habits continued from afar. He told Mary what crops to plant. He recommended leaving certain trees uncut and hired black settlers to clear his own land. He sent work assignments for his sons and Cyrus, a black farmhand hired by the Browns shortly after their arrival. He instructed Ruth and Henry about 'clearing up a piece of ground' and building a cabin for him, telling them to ask Eppes if he would help. The detailed extent to which Brown advised in absentia is clearest in an 1851 letter to the Thompsons, in which Brown lamented that a 'Mr. Hall' had left some boards lying around his house. If Hall was not going to use the boards, Brown, who had lent them, wanted Eppes to pick them up: 'I wish this to be attended to before the snow covers them up again., 39

Instructions like these not only revealed that Brown still arrogated the role of community advisor, but also expressed the two familiar concerns of a moral gardener with spatial and moral order. Raised among men who read morality on maps, Brown was as appalled by disarray around Hall's house as he was encouraged by visible improvements in the area like a 'fine Plank Road' or a good crop of 'Hay, Grain, Potatoes, Rutabaga \&c.' Among the assignments Brown gave his sons was fence-building, which recalls his 1840 criticism of Virginians who had 'no idea' of improvements like ‘enclosed pasture fields.' If Brown’s instructions about raising cabins, clearing trees, and cleaning up boards suggest the priority of spatial order, so does the fact that Brown spent his first months in Essex trying to clear up confusion about land claims. When he arrived Brown discovered that some black settlers had squatted on the land of a white farmer, 
and Brown wrote to Smith to help these men establish their legal titles to the lands they had improved. As with his 'New Connecticut' forbears, taming wilderness meant creating geographical order and improvements first, and during his fall 1850 stay, Brown therefore busied himself 'Surveying,' and 'tracing out old lost boundaries. ${ }^{40}$

'Surveying' meant moral surveillance, too. Visible disorder like that around Mr. Hall's house likely vexed Brown partly because it signified idleness. Conversely, signs of industry and virtue cheered Brown. One of his first letters to Hodges stressed 'the vast importance of sustaining the very best character for honesty, truth, industry and faithfulness,' and in 1852 , after 'a short visit,' Brown was gratified to find that 'the colored families' now had 'constant preaching on the Sabbath; and intelligence, morality, and religion appear to be all on the advance.' He also rejoiced when a religious revival swept the county. Despite his infrequent presence, Brown came to North Elba partly for the reasons Owen went to Hudson—as a supporter of civil and religious order. ${ }^{41}$

North Elba was an antislavery project, too, of course. Yet it was also another of his many efforts to order disordered country. Indeed, in Brown's family correspondence, discussions of the area's improvement were often as pronounced as concern for black settlers. After 1851, when Brown expressed desire to return to Essex, he usually mentioned scenic and agricultural advantages instead of abolitionist strategy. When Brown advised his son John Jr. to return to Essex in 1854, he cited the cheap farm prices, and in 1857, though Brown had once advised Smith deed-holders never to sell, he told John Jr. that 'many of the colored people who have not gone on their lands would sell out very low.' Brown's reversal shows partly that demographic shifts had doomed his original vision for North Elba. But it also shows that Brown always viewed North Elba partly like the surveyor and 'pioneer' he had always been. ${ }^{42}$ 


\section{'Words of Advice'}

After 1859, many of Brown's acquaintances claimed that he was already contemplating Harper's Ferry by the time he went to North Elba. Contemporary evidence is indecisive, but after the Fugitive Slave Law passed, Brown's tactics and rhetoric definitely began to shift. In January 1851, while in Springfield preparing to move back to Ohio, Brown wrote some 'Words of Advice' to an interracial vigilance committee called the League of Gileadites. He advised League members to arm themselves and 'make clean work with your enemies,' hanging together 'while a drop of blood remains; and be hanged, if you must.' Brown's militancy deepened in the 1850s as he fought in Kansas and then returned to the Midwest, where Brown began training raiders who would later descend on Virginia. ${ }^{43}$

Yet Brown's identity as his brothers' keeper survived even in his last nine years. After writing his (fittingly titled) 'Words of Advice,' Brown assured Mary, then in North Elba, that he had 'improved [his] leisure hours quite busily with colored people here, in advising them how to act... They very much need encouragement and advice.' Such comments suggest the persistence of Brown's felt duty to advise others, thereby improving his own hours and satisfying his responsibilities as a man. Moreover, while the militant parts of 'Words of Advice' stand out, other parts echoed 'Sambo's Mistakes.' 'Colored people' would have more white allies, Brown wrote, 'were they but half as much in earnest to secure their dearest rights as they are to ape the follies and extravagances of their white neighbors, and to indulge in idle show, in ease, and in luxury. ${ }^{44}$

If dispensing 'words of advice' remained central to Brown's role as an abolitionist, so did his self-image as a pioneer. His relocation to Kansas was, in addition to being an antislavery 
expedition, yet another move into untamed country in need of advice about how to manage. His sons also had moved to Kansas only after a lengthy discussion of other potential Western territories as destinations; northwestern Michigan had been floated as a possibility, and John Brown Jr. later recalled that the recently opened Kansas and Nebraska appealed initially because of the 'inducements' they offered to 'new beginners.' Brown's sons were continuing, like their father and his father before him, a mission to bring order to an unsettled frontier, and their grandfather Owen Brown encouraged them, not surprisingly, to 'begin right' in Kansas and 'make good provision for all civil and religious privileges, schools and meetings.' Such admonitions, deeply rooted in his Western Reserve past, doubtless informed Brown's initial understanding of Kansas as well. In February 1855, he told a friend he had 'undertaken to direct the opperations of a Surveying, \& exploring party' in Kansas, and an early letter after arriving in the Territory resembled the kind of surveying reports he had given when arriving in other new country like Virginia and Essex County — a report on the crops that would thrive there, and an evaluation of the locals. $^{45}$

Soon, of course, the Browns were at war with proslavery 'border ruffians,' and over the next several years he began recruiting small militias who first fought alongside him in Kansas and then followed him elsewhere. But what survived even then was Brown's old assumptions. His men agreed to vow 'obedience' to him, to maintain 'a gentlemanly ... deportment,' to forswear alcohol, and to 'contribute equally to all necessary labor' in the camp, advice that indicates how important order remained to Brown. Perhaps, then, it was not simply with tongue in cheek that Brown referred to his camp of raiders-in-training as 'school.' The codename was apt, for Brown's men divided their time between drilling, working, reading, and debating intellectual questions around campfires - almost like mobile manual labor schools in their 
combination of mental and physical culture. ${ }^{46}$

Brown's background cast a long shadow even over his Harper's Ferry plans. Some evidence suggests that after capturing the town, Brown intended to escape into yet another wilderness and plant another moral garden. In 1858 Brown drafted a 'Provisional Constitution and Ordinances' to 'govern our actions' in the Southern mountains, and Article XVI included mechanisms for reproducing civil and religious order. Brown's community would choose 'men of integrity, intelligence, and good business habits and capacity; and above all, of first-rate moral and religious character and influence, to act as civil officers of every description and grade, as well as teachers.' Manual labor would be mandatory, with the exception of Sunday, which was reserved for 'moral and religious instruction and improvement ... instruction of the young and ignorant, and the encouragement of personal cleanliness.' Profanity, 'indecent behavior,' inebriation and sexual immorality were outlawed. Article XLII required the establishment of 'schools and churches ... for the purpose of religious and other instructions. ${ }^{47}$

These regulations were accompanied by more startling ordinances like the provision that both women and men 'of good character' would be 'encouraged to carry arms openly.' Yet what survived most prominently in the Constitution was Brown's lifelong concern for bringing order out of moral and spatial wilderness. He evidently had in mind a long-lasting mountain community modeled partly on his original plans for North Elba. It is telling, for example, that while staying in Douglass's house for a few weeks in 1858 to draft his Provisional Constitution, Brown also drew sketches of what Douglass described as 'forts' that would be built in the mountains and connected by 'secret passages.' Brown even asked Douglass to acquire for him 'two smoothly planed boards, upon which he could illustrate, with a pair of dividers, by a drawing, the fortification which he meant to adopt.' From one angle, such a drawing indicates 
the new militancy of Brown's antislavery tactics. But it is also telling that Brown was still as handy with a surveyor's tools as with a rifle. Like Shipherd's plans for Oberlin, Brown's plans for a colony in the mountains began with spatial order and something like a map. ${ }^{48}$

Even Brown's related belief that it was his responsibility to educate people of color survived in his post-raid plans. After the raid, Brown's ally Richard Realf testified that Brown's men intended, after capturing Harpers Ferry, 'to organize the freed blacks in the mountains, where they would be taught all the business of life.' That claim seems plausible, given that even in the earlier Allegheny Mountain plan recalled by Douglass, Brown envisioned a semipermanent, interracial community that he would 'train' himself. ${ }^{49}$ The idea that Brown intended, even in his new abolitionist community, to serve again as a 'kind of father' is also strengthened by a discovery made by Clifton W. Tayleure, a Baltimore journalist and proslavery melodramatist, the day after Brown's capture. After accompanying some Marines to the Kennedy Farmhouse, Brown's headquarters before the raid, Tayleure purloined a gun, a pike, and a sheaf of papers found by Brown's bed. Among these papers was an old letterbook, which contained no other writing except for the undated manuscript of 'Sambo's Mistakes.' Why Brown still carried this manuscript with him, years after its composition, is unclear. But perhaps he believed the freedpeople he took to the mountains would still need his words of advice and kind instruction. ${ }^{50}$

\section{Moral Stewardship and Interracial Abolitionism}

This abridged narrative of Brown's life makes it possible to see both the long continuity of Brown's identity as a 'moral steward' as well as his contiguity to other reformers. Without discounting discontinuities in Brown's life or his differences from other abolitionists, it is clear 
that his career was not simply an aberration. Rather, he followed a course laid out for him by his background as a son of New Connecticut and the moral steward's errand there. To be sure, depicting Brown as a 'moral steward' does not offer us a comprehensive interpretation of Brown's complicated life, nor do I intend to argue that it does. In particular, it does not fully explain both why Brown's abolitionist career entered a more militant phase in the 1850s and why, nonetheless, his enterprises received mixed reactions from black abolitionists. But the account offered here makes sense of much of his life and suggests the need to reconsider recent interpretations that present Brown as a man who thought of himself as virtually 'black' and established exceptionally intimate relationships with people of color. These strong claims about Brown's anomalousness need to be balanced against evidence of his representativeness, especially since Brown's interracial relationships — which are now usually cited as the most unusual dimension of Brown's life_-are revealed only through fragmentary sources that admit multiple interpretations.

Consider, for example, North Elba. Brown's residence in that community is often cited as proof of his unusually intimate interracial ties, but since Brown's actual time living there was brief and there is a paucity of testimony about Brown from black North Elbans, characterizations of Brown's interracial relationships there usually rely on two kinds of sources: comments on the community by white observers or the Browns themselves, and comments by North Elbans recorded long after Brown's death.

An example of the first kind of source is an often-cited entry from the journal of Richard Henry Dana, Jr. During a mountain hike in June 1849, Dana stumbled upon the Browns' rented farm and observed in his journal that Brown 'had two negro men, one called $M r$. Jefferson, \& a negro woman' who helped Ruth cook breakfast. A few days later he returned, finding the family 
dining 'in the patriarchal mode. Mr. \& Mrs. Brown \& their large family of children, with the hired men \& women, including three negroes, all at the table together.' In 1871, Dana published excerpts from his journal, retrospectively reading these scenes as signs of egalitarianism. Most biographers have followed suit. But Dana's journal provides only a snapshot of the brief weeks before Brown's long absence, and we learn little here about the 'negroes' Dana met, beyond his report that they were "hired men \& women. ${ }^{, 51}$ A few black settlers did live with the Browns temporarily, but Dana's journal comports with other evidence suggesting that black North Elbans who spent time in Brown's household were his employees. Shortly after arriving in 1849, the Browns hired a black woman, 'Mrs. Reed,' as housekeeper, Thomas Jefferson as teamster, and Cyrus Thomas as a farmhand. Cyrus appears in the 1850 census as a twenty-three-old black 'laborer' living with the Browns, but by December 1850, Reed, Jefferson and Cyrus had all left, and Brown reported that 'we have no hired person about the family in Essex." 52

We know little about how these black employees viewed their relationship to the family or why they left. Brown's family usually remembered their father's employment of black North Elbans, some of whom did remain in contact with the Browns for years, as signs of his benevolence. But whether Mr. Jefferson or Mrs. Wait saw their jobs for the Browns as a token of egalitarianism, or simply as much-needed work, is unclear. What is clear, given Dana's comment that the family dined in 'patriarchal mode,' is that Brown still remained head of his household. While inviting people of color to his table represented inclusion, inclusion in Brown's household usually meant deference to his leadership, and contemporary sources give limited access to the ways black North Elbans perceived that 'patriarchal mode.' Even Hodges, who complimented Brown as one of the noblest men he knew in the final pages of his memoir, wrote those words 
before Brown became his neighbor. How their friendship fared after Brown moved to Essex is unclear. $^{53}$

Our access to the views of black North Elbans about Brown are mainly limited to distant recollections. Seventy years after the Harper's Ferry raid, Eppes's son, who was twelve years old or younger when Brown died, remembered sitting on Brown's knee as a child and singing a hymn at Brown's funeral. His father, Lyman Eppes Sr., had perhaps the longest association with the Browns of any black North Elban. In an interview conducted by a white reporter nearly thirty years after the raid, when Eppes was still leasing some land from Brown's children, he appeared as 'an aged colored man' with 'misty eyes' who spoke 'reverently of his friend and superior.' But the few details Eppes Sr. provided about Brown were impressionistic, and confirmed their infrequent interactions. After arriving, Brown lived in Essex 'off and on for two years' and 'did not stay in the mountains continuously; he came in and out.' He was a 'generous neighbor,' Eppes concluded, but 'he visited little.' 54

Recollections of Brown collected after Harper's Ferry give us some idea of what Brown's interracial relationships were like, but memories often obfuscate as much as they reveal. Brown's martyrdom and international celebrity affected the context in which everything about him was subsequently said or read. After 1859, as historian Benjamin Quarles noted, in death Brown became primarily a 'symbol, typically bearing its own reality however well or ill supported by the initial hard facts.' Indeed, even before his death, statements about Brown's interracial relationships were seldom only reportage. Such reports always had symbolic and rhetorical value as ways for abolitionists to goad other white Americans to repent from racial prejudice. Thus, the documentary record about North Elba, limited as it often is to the memories of two families, the 
Browns and the Eppeses, is only one instance of a general problem: the difficulty of separating symbol from fact. $^{55}$

To be sure, the symbols contained truth, just as post-1859 memories of Brown as a community-builder did. In September 1854, when trying to decide whether to return to Essex or go to Kansas, Brown asked the Thompsons to 'learn from Mr. Epps \& all the colored people (so far as you can) how they would wish, $\&$ advise me to act in the case,' since he had 'volunteered in their service.' That letter gives a tantalizing hint of Brown's egalitarianism, especially since, as we have seen, he was usually more disposed to advise than seek advice. But even this letter underlines the asymmetrical character of the record on North Elba, and his parenthetical remark ('so far as you can') suggests his tenuous access to 'the colored people.' The response to his request for advice is also unknown, and ultimately, Brown went to Kansas, which presents us with three ambiguous possibilities: either the 'colored people' asked Brown to leave; they were indifferent; or they advised him to stay and he left. In the end, a source that promises to illuminate the depth of Brown's interracial relationships at North Elba actually serves mainly as evidence of the way Brown viewed those relationships and himself. ${ }^{56}$

When we turn from North Elba to Brown's other interracial relationships, similar documentary problems arise: African American testimony is either freighted with symbolism or missing. The absence of contemporary testimony from African Americans is especially glaring in instances when Brown's imperiousness could easily have given offense, such as his use of the name 'Sambo' to point out black men's mistakes, or his criticism, in his 'Words of Advice' to the Gileadites, of free blacks who 'ape' white follies. Most biographers assert or imply that 'Sambo's Mistakes' was published in the Ram's Horn, suggesting black abolitionists were not offended by Brown's sententiousness or his adoption of a black persona, but there is no evidence 
that the Ram's Horn editors or any other black abolitionist ever saw 'Sambo's Mistakes.' The essay exists today only as the undated manuscript discovered by Tayleure, meaning it may never have been mailed, received, read, or published. If it was sent, Hodges might have received it after his last known compliment to Brown in his 1849 memoir, which means that the reactions of black readers to Brown's stern advice about their mistakes is unknown and perhaps unknowable. $^{57}$

Likewise, many biographers claim that 'Words of Advice' was signed and thus endorsed by 'forty-four black residents of Springfield.' Yet in this case, the manuscript no longer exists, and according to William Wells Brown, who published a selected transcription of the manuscript in 1870 , the forty-four names on the bottom were not signatures, but were 'all in the handwriting of John Brown.' In 1891, Franklin Sanborn printed the same manuscript, 'somewhat condensed,' including some 'resolutions' passed by the League that were omitted by Wells Brown. According to Sanborn, the forty-four names — not all of them belonging to black residentsfollowed these resolutions, and without the original, uncondensed manuscript, it remains technically possible that Brown copied the League's resolutions from another source and prefixed his 'Words of Advice,' or that he made the list of names himself as potential signatories. $^{58}$

These documentary problems do not mean that Brown did not cooperate with black activists. It is now indisputable that Brown, as Du Bois put it, worked with black men, and not simply for them. Yet the nature of the documentary record does leave uncertain whether Brown's relationships with black abolitionists were categorically more intimate and trusting than the interracial alliances of other white abolitionists. As historians Mia Bay and Manisha Sinha have both noted, the fact that Brown cooperated with black abolitionists and received their 
compliments did not make him unique. Other white abolitionists in Brown's milieus, both in the Western Reserve and in the East, also forged mutually respectful interracial ties. Garrison and his followers maintained long alliances with black reformers like Wells Brown and William Cooper Nell, for example, even after their well-known and bitter breaks with other black abolitionists like Frederick Douglass and James McCune Smith, both of whom also counted white Garrisonians as allies before fractures appeared..$^{59}$

Perhaps the crucial difference between Garrison's interracial relationships and Brown's is less that Brown's were clearly intimate, while Garrison's were strained, and more that the testimony about Garrison recorded by black abolitionists during his lifetime is much more voluminous and variegated than in Brown's case. To be sure, as numerous writers have noted, black Americans after Brown's death universally remembered him as a paragon of egalitarianism; they could safely do so since, unlike other white veterans of the movement, he was no longer around to contradict, by a thoughtless word or deed, the afterlife they gave him. Yet these remembrances of Brown reveal more about the way African Americans and their allies during and after the Civil War used the memory of abolitionism to press for greater equality than they reveal about the presence of strain or intimacy in Brown's actual interracial relationships. After all, even white abolitionists whose interracial relationships are definitely known to have been strained were eventually remembered positively by African Americans as part of a pantheon of white allies in the struggle against injustice. Douglass's accounts of his extremely fraught relationship with Garrison, for example, softened considerably in the years after the Civil War.

Significantly, too, despite the glowing paeans to Brown published after 1859, one can catch glimpses of fractures in his interracial relationships that might have grown wider if Brown 
had survived. Although Brown presented his Constitution at a convention of black abolitionists in Chatham, Canada, it is unclear how much Brown told black supporters about the raid. When his plans did become clear, many black abolitionists opposed the raid or declined to join, including Eppes, McCune Smith, Martin Delany, Loguen, Garnet, and George De Baptiste, who reportedly opposed Brown to his face at a meeting in Detroit. Some evidence suggests that Brown reacted angrily to such opposition. When Hugh Forbes, the English military expert hired by Brown to train his men, began blackmailing Brown, Brown accused McCune Smith of helping Forbes. Delany recalled that when he and others questioned Brown's plan at Chatham, Brown rose angrily and called Delany a 'coward.' According to a much later report of the Detroit meeting with DeBaptiste, also attended by Douglass, Brown grew 'wrathy' and 'asked Douglass if he was a coward' when Douglass 'objected to Brown's plan.' When Douglass went to meet Brown at a last meeting in Chambersburg, Pennsylvania, and finally learned of Brown's plan in detail, Brown appealed to Douglass for over an hour to join him, but in vain. ${ }^{60}$

Determining the depth of these disagreements is difficult. After 1859, Douglass insisted that he and Brown left Chambersburg on friendly terms and denied the quarrel in Detroit. But given Brown's by then heroic status, perhaps there was little else Douglass could have said. Brown's relatives, at least, recalled the last meeting with Douglass differently. Douglass was devoured by 'conceit \& self importance,' according to multiple comments by Annie Brown, who was present with her father in Maryland before the raid, and many family members claimed Douglass reneged on a promise to join Brown. Some sources attributed bitterness to Brown himself. In 1909, one friend and supporter of Brown's from Massachusetts, recalling a visit with Brown in his jail cell, said Brown 'had no fondness for Fred Douglass.... Once I heard him say to my husband, of some defeated plan, some great opportunity lost, 'That we owe to the famous 
Mr. Frederick Douglass!' and he shut his mouth in a way he had when he thought no good.' Annie claimed in the 1880 s that 'Father told me on his return from Chambersburg after meeting him, 'Douglass has disappointed and deceived me."

These post-1859 recollections, of course, cannot be taken at face value, any more than glowing recollections of Brown. But they raise the possibility that if Brown had survived his raid, cracks in his relationships with abolitionists like Douglass may have widened. In the case of other strained interracial abolitionist relationships, like that between Garrison and Douglass, estrangement began when black abolitionists began to perceive what Douglass once called a spirit of 'overseership' in white abolitionists. Similar perceptions certainly may have been one source of friction between Brown and his allies on the eve of the raid.

Brown's friend Richard Hinton, for example, claimed that McCune Smith opposed the raid because he favored a 'separate' plan led by blacks themselves and wanted 'no help from white men.' Osborne Anderson, the only black raider to survive Harper's Ferry, wrote in 1861 that 'it has been a matter of inquiry, even among friends, why colored men were not commissioned by John Brown to act as captains, lieutenants, \&c,' and while Anderson insisted 'colored men' had been offered commissions, equally significant may be the perception 'among friends' that Brown had not. Perhaps black leaders who once saw Brown as a supporter of their independently directed plans were disappointed when he came to expect support for his. Perhaps, too, Brown's secrecy and dismissal of all objections reminded some black abolitionists of painful disagreements with others. In his 1882 memoir, for instance, Douglass's account of the Chambersburg meeting, at which Brown would not heed his warnings, echoed his earlier disagreements with Garrisonians over his decision to publish a newspaper: 'I laboured hard to convince them that my way of thinking about the matter was the right one, but without success.' 
Likewise, Douglass remembered that at Chambersburg he 'opposed [Brown's Harpers Ferry] measure with all the arguments at my command,' but Brown was 'not to be shaken by anything I could say.' Perhaps, if Harpers Ferry had ended differently, Douglass would have later remembered Chambersburg as the point at which his relationship with Brown began to fray along the same ragged edges as his relationship with Garrison. ${ }^{62}$

The important point here, however, is that the documentary record on Brown and the truncation of his career make it difficult to establish that Brown's interracial relationships were uniformly intimate or strained. As DeCaro rightly notes, 'the actual feelings of black male activists toward John Brown in the 1840s-50s, no doubt ranging from warm friendship and admiration to resentment and criticism, will never be fully known. ${ }^{63}$ What can be known with more confidence is the way that Brown viewed himself. Essays like 'Sambo's Mistakes' and 'Words of Advice,' along with Brown's letters and the various locations in which he lived, disclose more about Brown's self-image than about his achievement of interracial intimacy. Brown's long-standing 'peculiarity for insisting on order,' as his son described one of his father's clearest traits, reveals less that he was a harbinger of twenty-first-century racial egalitarianism than that he was, in some respects, a representative nineteenth-century moral reformer - a man for whom the idea that all men were his brethren never displaced his image of himself as his brothers' keeper. ${ }^{64}$

Brown's importance to our understanding of interracial abolitionism is not reduced by this possibility, but enhanced. His representativeness casts light on what was possible in the nineteenth century no less than his distinctiveness would. Indeed, the recent tendency to distinguish Brown as an unequalled egalitarian with other abolitionists of his time and place encourages scholars to focus discussions of interracial cooperation on the question of whether 
white abolitionists remained prejudiced or, in supposedly exceptional cases like Brown's, overcame prejudice. Reducing the success or failure of interracial alliances to the absence or presence of prejudice is tempting, because it suggests that white abolitionists could have achieved intimate interracial relationships simply by setting bigotry aside. But the more complicated truth is that the very same identities that made interracial abolitionism possible in the first place could strain interracial alliances as well. Brown's self-image as his brothers' keeper, after all, initially helped motivate his decision to move to North Elba, to propose a black school, to plan an interracial community, and, in short, to forge interracial relationships.

Yet his moral stewardship, like other white abolitionists' plans for elevating the colored people, created a thorny dilemma. To advise African Americans on taking their place as men meant, in Brown's worldview, to fit them for stewardship of their own. But that meant accepting that black abolitionists might one day confront Brown with advice contrary to his own, as some evidently did in the final months of his life. Even in the absence or relative absence of racial prejudice, submitting to the stewardship of others was seldom easy for a brothers' keeper. Impossible though it is to know how Brown's interracial relationships would have fared if he had not died in 1859, it is plausible to wonder if, in such an event, Chambersburg and Chatham would have become not the capstones of Brown's career, but the moments at which a central paradox in the concept of antislavery moral stewardship, a worldview that wedded racial egalitarianism with a still hierarchical view of social relationships, boiled rapidly to the surface of Brown's interracial brotherhood. 


\section{NOTES}

I would like to thank the numerous people who read earlier versions of this article and offered invaluable critiques and comments, including Erica Ball, John Boles, Elizabeth Escobedo, Randal Hall, Catherine Jones, Gale Kenny, Richard Newman, Elaine Parsons, Edward Rugemer, members of the Houston Area Southern Historians reading group, and my Spring 2007 and Fall 2008 students at the University of Denver and Rice University—especially Lyndsay Thompson, who asked the question in class that sparked the research for this piece. Special thanks are due to those who commented on multiple drafts and shared insights from their own research-Bonnie Laughlin-Schultz, James Brewer Stewart, and Ronald G. Walters.

${ }^{1}$ Evan Carton, Patriotic Treason: John Brown and the Soul of America (New York: Free Press, 2006), 93-4; John Stauffer, The Black Hearts of Men: Radical Abolitionists and the Transformation of Race (Cambridge, MA: Harvard University Press, 2002), 1-2; David S. Reynolds, John Brown, Abolitionist: The Man Who Killed Slavery, Sparked the Civil War, and Seeded Civil Rights (New York: Knopf, 2005); Louis A. DeCaro, Jr., 'Fire from the Midst of You': A Religious Life of John Brown (New York: New York Univeristy Press, 2002); Louis A. DeCaro, Jr., John Brown, The Cost of Freedom: Selections from His Life \& Letters (New York: International, 2007); Zoe Trodd and John Stauffer, eds., Meteor of War: The John Brown Story (Maplecrest, NY: Brandywine, 2004). 
${ }^{2}$ Stauffer, Black Hearts of Men, 3; Reynolds, John Brown, 51.

${ }^{3}$ W. E. B. Du Bois, John Brown, ed. David Roediger (New York: Modern Library, 2001), xxv. On Brown's contested legacy, see Merrill D. Peterson, John Brown: The Legend Revisited (Charlottesville, VA: University of Virginia Press, 2002).

${ }^{4}$ Mary Land, 'John Brown's Ohio Environment', Ohio State Archaeological and Historical Quarterly 57, no. 1 (January 1948): 24.

${ }^{5}$ Du Bois, John Brown, Xxv.

${ }^{6}$ Robert McGlone's new biography, which appeared as this article was being completed, also emphasizes the importance of Brown's early life, though McGlone focuses more on Brown's family and extended kin network, arguing that 'John's world' was largely 'bounded' by his father's and drawing attention to the singularity of the Brown clan. My interest here is more in placing both John and his father within the larger world of the Western Reserve. See Robert E. McGlone, John Brown's War against Slavery (New York: Cambridge University Press, 2009), 67.

${ }^{7}$ Clifford S. Griffin, Their Brothers' Keepers: Moral Stewardship in the United States, 1800-1865 (New Brunswick, NJ: Rutgers University Press, 1960), x.

8 Louis Ruchames, ed., John Brown, The Making of a Revolutionary: The Story of John Brown in His Own Words and in the Words of Those Who Knew Him (New York: Grosset \& Dunlap, 1969), 44; Amy DeRogatis, Moral Geography: Maps, Missionaries, and the American Frontier (New York: Columbia University Press, 2003), 97. 
9 DeRogatis, Moral Geography, 19, 90-126.

10 Edward Alanson Miller, The History of Educational Legislation in Ohio from 1803 to 1850 (Chicago: University of Chicago, 1920), 75-98; Kenneth H. Wheeler, 'How Colleges Shaped a Public Culture of Usefulness', in The Center of a Great Empire: The Ohio Country in the Early American Republic, eds. Andrew R. L. Cayton and Stuart D. Hobbs (Athens, OH: Ohio University Press, 2005); Paul Goodman, 'The Manual Labor Movement and the Origins of Abolitionism', Journal of the Early Republic 13, no. 3 (Autumn 1993): 355-88; Laura Graham, 'From Patriarchy to Paternalism: Disestablished Clergymen and the Manual Labor School Movement in Antebellum America' (PhD diss., University of Rochester, 1993); Robert H. Abzug, Passionate Liberator: Theodore Dwight Weld and the Dilemma of Reform (New York: Oxford University Press, 1980), 58-82.

11 DeRogatis, Moral Geography, 157-66, Shipherd quoted on 160, 162

12 ‘Owen Brown’s Autobiography’, MS05-0016, Boyd B. Stutler Collection Database, West Virginia Memory Project, http://www.wvculture.org/hiSTory/wvmemory/jb.aspx; Gerald W. McFarland, A Scattered People: An American Family Moves West (New York: Pantheon Books, 1985), 68-77; Frederick Clayton Waite, Western Reserve University, the Hudson Era: A History of Western Reserve College and Academy at Hudson, Ohio, from 1826 to 1882

(Cleveland: Western Reserve University Press, 1943), 23-30, 44-5; DeCaro, 'Fire From the Midst', 20-9, 47; Natalie Ann Naylor, 'Raising a Learned Ministry: The American Education Society, 1815-1860' (EdD diss., Columbia University, 1971), 242-57. 
13 'Owen Brown's Autobiography'.

14 Ruchames, John Brown, 174, 176 (Foreman), 178 (Delamater); Franklin B. Sanborn, The Life and Letters of John Brown, Liberator of Kansas, and Martyr of Virginia (Boston: Roberts Brothers, 1891), 32; Anne W. Stewart, 'John Brown: From the Record; The Crawford County Years: 1827-1835; The Young Family Man', Journal of Erie Studies 31, no. 2 (Fall 2002), 44-78; Stephen B. Oates, To Purge This Land with Blood: A Biography of John Brown (New York: Harper \& Row Publishers, 1970), 19-22; DeCaro, John Brown, Cost of Freedom, 20-1.

${ }^{15}$ Ruchames, John Brown, 179; Oates, To Purge This Land, 48; Robert Samuel Fletcher, A History of Oberlin College: From Its Foundation through the Civil War (Oberlin, OH: Oberlin College, 1943), 1:34-43, 85-90, 189-90; C. H. Cramer, Case Western Reserve: A History of the University, 1826-1976 (Boston: Little, Brown and Company, 1976), 158-62; Waite, Western Reserve University, 71-80.

16 Ruchames, John Brown, 56.

17 Abzug, Passionate Liberator, 98-122; Fletcher, History of Oberlin College, 1:142-9, 236-53; McFarland, Scattered People, 108-18; Milton C. Sernett, Abolition's Axe: Beriah Green, Oneida Institute, and the Black Freedom Struggle (Syracuse, NY: Syracuse University Press, 1986), 17-30; Lawrence B. Goodheart, Abolitionist, Actuary, Atheist: Elizur Wright and the Reform Impulse (Kend, OH: Kent State University Press, 1990), 37-60. On the Western 
Reserve Anti-Slavery Society, see 'New Anti-Slavery Societies,' The Abolitionist (Boston) 1, no. 10 (October 1833), 159.

${ }^{18}$ Ruchames, John Brown, 50-1.

19 Weld quoted in Abzug, Passionate Liberator, 94; Lawrence J. Friedman, Gregarious Saints: Self and Community in American Abolitionism, 1830-1870 (Cambridge, UK: Cambridge University Press, 1982), 167.

20 Goodman, 'Manual Labor Movement'; Sernett, Abolition's Axe; James Brewer Stewart, 'The New Haven Negro College and the Dynamics of Race in New England, 1776-1870', in Abolitionist Politics and the Coming of the Civil War (Amherst, MA: University of Massachusetts Press, 2008), 172-202; Bertram Wyatt-Brown, Lewis Tappan and the Evangelical War Against Slavery (Cleveland: Press of Case Western Reserve University, 1969), 121-9;

Stauffer, Black Hearts of Men, 126-7, 152.

${ }^{21}$ Ruchames, John Brown, 50; typed copy of Owen's letter excerpted from Report of the Second Anniversary of the Ohio Anti-Slavery Society, Held in Mount Pleasant, Jefferson County, Ohio, on the $27^{\text {th }}$ of April, 1837 (Cincinnati, 1837), MS05-0003 AB, Stutler Collection Database.

22 Sanborn, Life and Letters of John Brown, 134-5; Ruchames, John Brown, 55.

23 Ruchames, John Brown, 174.

${ }^{24}$ Willard B. Gatewood, Jr., ed., Free Man of Color: The Autobiography of Willis Augustus Hodges (Knoxville, TN: The University of Tennessee Press, 1982), 78; Oates, To Purge This Land, 51-64; DeCaro, 'Fire from the Midst', ch. 12; Frederick Douglass, The Life 
and Times of Frederick Douglass, from 1817 to 1882, Written by Himself (London: Christian Age Office, 1882), 238-40.

${ }^{25}$ Douglass, Life and Times, 237; Trodd and Stauffer, Meteor of War, 55.

26 Brown quoted in DeCaro, 'Fire from the Midst', 154; Sernett, Abolition's Axe, 52. For Delamater's college education, see Stewart, 'John Brown', 54.

27 See Goodheart, Abolitionist, Actuary, Atheist, 58; Abzug, Passionate Liberator, 95, 101.

28 Ruchames, John Brown , 69-72.

29 'Owen Brown's Autobiography'; Goodman, 'Manual Labor Movement', 365.

30 Ruchames, John Brown, 70, 71.

31 Stauffer, Black Hearts of Men, ch. 5; Gatewood, Free Man of Color, xlii-xlv. 32 John Brown [JB] to John Brown, Jr. [JBJr], 24 April 1848, John Brown Jr. Papers, Ohio Historical Society [OHS]; DeCaro, 'Fire from the Midst', 154; James H. Henderson to Henry Highland Garnet, 29 January 1849, in North Star, February 16, 1849; Gatewood, Free Man of Color, 80; 'Movements of the Grantees of the City of Troy', North Star, 10 November 1848; 'Gerrit Smith's Land', North Star, December 8, 1848.

33 Ruchames, John Brown, 75; Sanborn, Life and Letters, 97.

34 DeCaro, 'Fire from the Midst', 154.

35 JB to JBJr, 24 April 1848, OHS. 
36 Ruth Brown [RB] to JBJr and Wealthy Brown [WB], 23 May 1850, OHS. For examples of Brown referring to Ohio, not Essex, as 'home' after March 1851, see JB to JBJr, 20 October 1851, OHS; JB to Henry Thompson [MB], 4 June 1855 (photocopy), Edwin N. Cotter, Jr., Collection on John Brown, SUNY-Plattsburgh [SUNY-P], 1/4. My North Elba timeline is reconstructed from Oates, To Purge This Land, 68-9, 71, 75-81, 85-6; Ruchames, John Brown, 79, 81; and these letters at OHS: Jason Brown to JBJr, 17 August 1849, OHS; JB to JBJr, 9 November 1849, OHS; JB to JBJr, 4 November 1850, OHS; JB to MB, 17 January 1851, OHS; Thomas Thomas to JBJr., 16 June 1851 OHS; JB to JBJr, 6 May 1851, OHS. Stauffer refers to North Elba or 'Timbucto' as Brown's 'permanent' home in Black Hearts of Men, 3, 173. Reynolds notes that 'trips often kept [Brown] away' but does not convey how often Brown was absent, and claims that for Brown, 'North Elba was home'. See Reynolds, John Brown, 126, 132.

37 John Stauffer, ed., The Works of James McCune Smith: Black Intellectual and Abolitionist (Oxford, UK: Oxford University Press, 2006), 314; 1850 United States Census, retrieved from AncestryLibrary.com; 'Communications', Frederick Douglass' Paper, September 30, 1853; Notes from 1855 State Census, SUNY-P 11/136; 1860 United States Census, retrieved from AncestryLibrary.com. See also Lyman E. Eppes to 'Mr. Editor', Frederick Douglass' Paper, July 21, 1854. For examples of Brown's family's interactions with North Elbans, and also of Brown's children as intermediaries between them and Brown, see RB to MB, 7 September 1849, John Brown Papers, Folder 1.12, MS 1246 (microfilm), Kansas State Historical Society [KSHS]; Ella Thompson Towne, 'My Recollections of North Elba', 15 June 1932, SUNY-P 6/68; Lou V. Chapin, 'The Last Days of Old John Brown', Overland Monthly (April 1899), 326; 
RB to MB, 1 October 1849 (copy), Folder 2, Franklin Benjamin Sanborn Collection on John Brown, bMS Am 1342.2, Houghton Library, Harvard University [HU]; RB to MB, 31 October 1849, SUNY-P 11/133; RB to JB, 10 April [1850], Folder 1.13, KSHS; Annie Brown to JBJr., 19 July 1857, OHS; RB to WB, 6 August 1850, OHS.

38 'John Brown in Essex'; 'Movements of the Grantees '.

${ }^{39}$ See JB to MB, 12 April 1850, SUNY-P 20/239; JB to HT and RB, 10 May 1853, Stutler Collection Database, MS01-0043 AB; JB to RB and HT, 29 December 1852, SUNY-P 1/1; Sanborn, Life and Letters, 108.

${ }^{40}$ Ruchames, John Brown, 81-2. See also JB to JBJr, 4 November 1850, OHS; JB to MB, 12 April 1850,. On the confusion surrounding land claims, see Mary MacKenzie, 'Samuel Jefferson-Thomas Jefferson' (n.p., 1994), SUNY-P 11/136; JB to Gerrit Smith, 20 June 1849 (typed copy), SUNY-P 12/143; James H. Henderson to Gerrit Smith, 15 October 1850 (typed copy), SUNY-P 20/239; JB to Gerrit Smith, 8 November 1849 (typed copy), SUNY-P 12/140. 41 'John Brown in Essex'; Sanborn, Life and Letters, 108-110; JB to 'Dear Children,' 21 February 1853, OHS.

42 JB to JBJr, 3 April 1854, OHS; JB to JBJr, 14 February 1857, OHS. See also JB to JBJr, 26 June 1854, OHS; JB to JBJr, 3 August 1854, OHS; JBJr to RB and HT, 12 January 1857, SUNY-P 6/65; Oliver Brown to Salmon Brown, 13 January 1857, HU.

${ }^{43}$ Ruchames, John Brown, 84-86.

${ }^{44}$ Ruchames, John Brown, 83, 84. 
45 JBJr, “Recollections of Early Days in Kansas," [1896], OHS; Owen Brown quoted in McGlone, John Brown's War, 90; Oswald Garrison Villard, John Brown, 1800-1859: A Biography Fifty Years After (Boston: Houghton Mifflin, 1910), 84; Ruchames, John Brown, 956. See also Henry Thompson to JBJr and Wealthy Brown, 7 May 1854, OHS.

46 Villard, John Brown, 666-7. See DeCaro, John Brown, Cost of Freedom, 145; Smith, 'Reminiscences', 233; Oates, To Purge this Land, 220-3.

47 Trodd and Stauffer, Meteor of War, 109-20.

48 Douglass, Life and Times, 276.

${ }^{49}$ Report [of] the Select committee of the Senate appointed to inquire into the late invasion and seizure of the public property at Harper's Ferry (Washington, D.C.: n.p., 1860), Appendix, 97; Douglass, Life and Times, 289.

${ }^{50} \mathrm{C}$. W. Tayleure to JBJr, 15 June 1879, Folder 2.22, KSHS; Tayleure to President of the Maryland Historical Society, 3 November 1883, Maryland Historical Society, MS 2008.

51 Robert F. Lucid, ed., The Journal of Richard Henry Dana, Jr., vol. 1 (Cambridge, MA: Harvard University Press, 1968), 364-5, 373-5; R.H. Dana, Jr., 'How We Met John Brown', Atlantic Monthly (July 1871): 6-7.

52 Sanborn, Life and Letters, 99-100; Ruchames, John Brown, 82.

${ }^{53}$ Hodges finished his autobiography on February 12, 1849, according to Gatewood, Free Man of Color, xlvii. Brown moved in May. 
54 'John Brown Rests Amid the Mountains', New York Times, October 20, 1929; DeCaro, 'Fire from the Midst', 178-9; newspaper clippings in SUNY-P 11/132; 'John Brown's Adirondack Life: His Home in the Woods and His Burial; Recollections of a Colored Companion', New York Daily Tribune, October 17, 1886. On Eppes’s renting of family land after 1859, see JBJr. to Lyman E. Eppes, 1 November 1885, Stutler Online MS05-0056 AB; letters from Lyman E. Eppes, Sr., to JBJr, dated 10 November 1885, 5 November 1886, 29 December 1887, 26 January 1893, all in SUNY-P 11/133. Eppes later sent a clipping of his New York Daily Tribune interview to JBJr noting that he saw 'a goodly number of errors in it, but I can overlook them as I trust you will'. What the 'errors' were is unspecified. See Eppes to JBJr., 5 November 1886, SUNY-P 11/133.

55 Benjamin Quarles, Allies for Freedom: Blacks and John Brown (New York: Oxford University Press, 1974), x.

56 Ruchames, John Brown, 94.

57 The single extant issue of the Ram' Horn is on microfilm in the Library of Congress's series of Miscellaneous Negro Newspapers. 'Sambo's Mistakes' is not in it. Internal evidence indicates the essay was written at least sometime after mid-1848, since it refers to the recent emancipation of slaves by France. On biographers' claims about the essay's publication, cf. Quarles, Allies for Freedom, 21; Oates, To Purge this Land, 59; Gatewood, Free Man of Color, vii, xli; Carton, Patriotic Treason, 114; Stauffer, Black Hearts of Men, 173; DeCaro, 'Fire from the Midst', 155, 314n8. See also Sanborn, Life and Letters of John Brown, 128; Trodd and Stauffer, Meteor of War, 55. 
58 Trodd and Stauffer, Meteor of War, 77; William Wells Brown, 'John Brown and the Fugitive Slave Law', New York Independent, March 10, 1870; Sanborn, Life and Letters, 124-7. The manuscript's title suggests the 'Words of Advice' were 'adopted' by the League, but how and to what extent is unclear.

59 Manisha Sinha, "'His Truth is Marching On”: John Brown and the Fight for Racial Justice', Civil War History 52, no. 2 (June 2006): 165; Mia Bay, 'Abolition and the Color Line', review of The Black Hearts of Men by John Stauffer, American Quarterly 55, no. 1 (March 2003): 109-10.

${ }^{60}$ Quarles, Allies for Freedom, 53; Frank A. Rollin, Life and Public Services of Martin R. Delany (Boston: Lee and Shepard, 1883), 93; 'The Gideon of God's Enslaved in the United States', Detroit Post, rept., National Anti-Slavery Standard, 9 April 9, 1870; Douglass, Life and Times, 276, 278.

61 'Gideon of God's Enslaved'; Douglass, Life and Times, 276, 278; Ruchames, John Brown, 247; Annie Brown Adams, untitled mss., Folder 1.03, MS 1245 (microfilm), KSHS. See also DeCaro, John Brown, Cost of Freedom, 69.

${ }^{62}$ Richard J. Hinton, John Brown and His Men: With Some Account of the Roads They Traveled to Reach Harper's Ferry (New York: Funk \& Wagnalls, 1894), 162-3; Osborne P. Anderson, G. D. Whitmore, and E. H. Sears, A Voice from Harper's Ferry: A Narrative of Events at Harper's Ferry (Boston: By the Author, 1861), 14; Douglass, Life and Times, 226. See also Quarles, Allies for Freedom, 80. 
${ }^{63}$ DeCaro, John Brown, Cost of Freedom, 62

${ }^{64}$ Villard, John Brown, 1800-1859, 424. 